e-Jurnal Ilmiah BIOSAINTROPIS (BIOSCIENCE-TROPIC)

Volume 6/ No.: 2 / Halaman 58 - 63 / Januari Tahun 2021

ISSN : 2460-9455 (e) - 2338-2805(p)

\title{
Studi Subkronik 28 Hari: Uji Toksisitas Ekstrak Metanolik Kombinasi Scurulla atropurpurea dan Dendrophthoe pentandra Terhadap Kerusakan Fungsi Ginjal Tikus Wistar Betina
}

\section{Study of Subchronic during 28 days: Toxicity Test of Methanolic Extract Combination of Scurulla atropurpurea and Dendrophthoe pentandra Against Malfunctioning Kidney Function of Female Wistar Rats}

\author{
Malia Anjani $^{1 *}$, Nour Athiroh Abdoes Sjakoer $^{2 * *}$, Nurul Jadid Mubarokati ${ }^{3}$ \\ 1,2,3 Jurusan Biologi FMIPA Universitas Islam Malang, Indonesia
}

\begin{abstract}
ABSTRAK
Benalu teh (Scurrula atropurpurea (B1.) Dans) dan Benalu Mangga (Dendrophthoe pentandra) merupakan tanaman parasit yang hidup menumpang pada tanaman teh dan mangga, sangat berpotensi sebagai obat-obatan, karena mengandung senyawa flavonoid yaitu quercetin dan rutin. Flavonoid berperan sebagai penyedia antioksidan alami yang melindungi ginjal dari zat radikal bebas. Kerusakan fungsi ginjal diindikasi dari kadar kreatinin, BUN, urea, dan histopataologi ginjal. Tujuan penelitian ini adalah mengetahui toksisitas pemberian kombinasi ekstrak benalu teh dan benalu mangga (EMBTBM) terhadap kerusakan fungsi ginjal pada tikus wistar betina selama 28 hari, dengan metode true eksperimental design. Data kadar kreatinin, bun, urea, dan histopatologi ginjal dianalisis menggunakan uji ANOVA. Penelitian ini menggunakan hewan coba berjumlah 20 ekor tikus putih betina Hewan coba dibagi menjadi 4 kelompok denga 5 ekor tikus pada tiap kelompok. Kelompok 1sebagai kontrol, sementara kelompok 3 dan 4 diberi perlakuan EMBTBM. Hasil penelitian menunjukan bahwa perbedaan nilai signifikan antara semua kelompok yaitu $\mathrm{p}>0.05$. EMBTBM yang disondekan pada tikus wistar betina selama 28 hari dengan dosis yang diberikan yaitu $250 \mathrm{mg} / \mathrm{KgBB}, 500 \mathrm{mg} / \mathrm{KgB}$, dan $1000 \mathrm{mg} / \mathrm{KgBB}$ menurunkan kadar kreatinin, bun, urea dan nekrosis sel ginjal, dalam hal ini pemberian EMBTBM cenderung aman dan tidak menimbulkan sifat toksik pada kerusakan fungsi ginjal tikus wistar betina.
\end{abstract}

Kata Kunci : Ekstrak, Fungsi ginjal, dan Subkronik.

\section{ABSTRACT}

Mistletoe tea (Scurrula atropurpurea (Bl.) Dans) and Mistletoe Mango (Dendrophthoe pentandra) are parasitic plants that live on tea and mango plants, very potential as medicines, containing several secondary metabolite compounds such as flavonoids (quercetin). Flavonoids can act as natural antioxidants that can protect the kidneys from free radicals. Damage to kidney function can indicate from creatinine, BUN, urea, and renal histopathology. The purpose of this study was to determine toxicity of a combination of Mistletoe tea extract and mango mistletoe (EMBTBM) to damage kidney function in female Wistar rats for 28 days, using the true experimental design method. Data on creatinine, bun, urea, and renal histopathology data were analyzed using the ANOVA test. The number of test animals is 20 female white rats divided into four groups; each group there are five rats. Group 1 a control, then groups 3, and 4 as treatment. Based on the results of the study showed that statistically significant between all groups was $p>0.05$. Therefore, EMBTBM given to female rats for 28 days at a dose of $250 \mathrm{mg} / \mathrm{KgBB}, 500 \mathrm{mg} / \mathrm{KgBB}$, and $1000 \mathrm{mg} / \mathrm{KgBB}$ reduces levels of creatinine, bun, urea and renal cell necrosis, in this case, the administration of EMBTBM tends to be safe and does not cause rise toxic properties in damage to kidney function in female Wistar rats.

Keywords: Subchronic, kidney function, and extract.

\footnotetext{
*) Malia Anjani, Universitas Islam Malang, Biologi FMIPA, Jl. MT. Hariyono 193, Malang 65144 Tlp. 085785226661. Email : anjanimalia@gmail.com

$\left.{ }^{* *}\right)$ Dr. Nour Athiroh Abdoes Sjakoer, S.Si., M.Kes Universitas Islam Malang, Biologi FMIPA, Jl. MT. Hariyono 193, Malang 65144 Tlp 081330017206. Email : nour.athiroh@unisma.ac.id
}

Diterima Tanggal 1 Januari 2020 - Dipublikasikan Tanggal 25 Januari 2021 
e-Jurnal Ilmiah BIOSAINTROPIS (BIOSCIENCE-TROPIC)

Volume 6/ No.: 2 / Halaman 58 - 63 / Januari Tahun 2021

ISSN : 2460-9455 (e) - 2338-2805(p)

\section{Pendahuluan}

Indonesia dikenal memiliki keanekaragaman hayati terluas ke-2 di dunia, terdapat 30.000 jenis tumbuhan, 7000 diantaranya memiliki khasiat namun hanya 2500 saja yang dijadikan tanaman obat. Salah satu tanaman herbal di Indomnesia adalah benalu teh dan benalu mangga, Analisis fitokimia yang dilakukan diperoleh hasil yaitu terdapat senyawa metabolit sekunder yaitu flavonoid yang berfungsi untuk menurunkan kadar hipertensi [1].

Pada penelitian tahun-tahun sebelumnya juga diperoleh kandungan senyawa bioaktif. Dibuktikan secara Invitro, kontraktilitas pembuluh darah arteri pada ekor tikus terpisah melalui peran endotel. Pasca pemberian ekstrak metanolik benalu teh (EMSA) cenderung turun [2][3]. Dan secara In vivo pemberian EMSA NO kadarnya meningkat, Malondialdehyde kadarnya turun dan dapat dijadikan sebagai perbaikan stress oksidatif serta disfungsi Endotel [4][5][6].

Dalam bidang ilmu farmakokinetik, proses distribusi, metabolisme, dan ekskresi (ADMA) terjadi saat zat masuk dalam tubuh. Organ ginjal sebagai organ ekskresi utama berperan penting dalam mengeluarkan zat hasil metabolisme tubuh. Salah satu zat penyebab kerusakan fungsi ginjal adalah kadar kreatinin yang tinggi [7]. Riset yang sudah dilakukan sebelumnya adalah pengujian toksisitas benalu teh pada mencit. Kadar SOD (Superoxide dismutase) dan MDA (Malondialdehyde) yang dihasilkan tidak berbeda nyata dengan kontrol (inpress). Uji subkronik EMSA pada tikus putih Rattus norvegicus selama 28 hari menunjukkan bahwa pemberian EMSA tidak menyebabkan gangguan serum biokimia klinis terhadap kreatinin tikus (fungsi ginjal) [8]. Berdasarkan hal tersebut, perlu adanya uji biokimia klinis kadar urea, bun, kreatinin, dan histopatologi pada ginjal tikus wistar betina (Rattus norvegicus) selama 28 hari (subkronik) setelah perlakuan ekstrak metanolik kombinasi benalu teh dan mangga (EMBTBM).

\section{Material dan Metode}

\section{Bahan dan Alat}

Bahan dalam penelitian ini antara lain susu pap sebagai pakan tikus, akuades, Daun Scurrula atropurpurea (Bl) Dans dan Dendrophthoe pentandra, anatesi eter, metanol 90\%, ketamine untuk bius, larutan PBS, tikus wistar betina (Rattus norvegicus) (umur: 2 bulan, BB: 200-300 gram). Benalu teh dan benalu mangga diidentifikasi di Balai Materia Medica Batu, Malang, Jawa timur

Alat yang dipergunakan antara lain kandang tikus 40x30 cm, penutup kandang, botol minum tikus, timbangan digital, blender, beaker glass, corong, erlenmeyer, freezer, gunting, handscoon, masker, mikrosentrifus, oven, pinset, papan beda, sectio set, mikroskop.

\section{Metode}

Penelitian dilaksanakan sesuai persetujuan dari Komisi Etika Penelitian Fakultas Kedokteran Universitas Brawijaya Malang (Ethical Clearance) dengan nomor: 369/EC/KEPK/06/2015. Metode yang digunakan pada penelitian ini yaitu True Eksperimental Design dengan Rancangan Acak Lengkap (RAL) dilakukan pada 20 ekor tikus dengan 3 perlakuan dan 1 kontrol. Setiap perlakuan terdapat 5 kali ulangan, diberi perlakuan dosis sebanyak $250 \mathrm{mg} / \mathrm{KgBB}, 500 \mathrm{mg} / \mathrm{KgBB}$, dan 1000 $\mathrm{mg} / \mathrm{KgBB}$. EMBTBM dipaparkan pada tikus wistar betina (Rattus norvegicus) selama 28 hari dan dilakukan pemeriksaan biokimia klinis fungsi ginjal dan pengamatan histopatologi ginjal tikus wistar betina.

\section{Cara Kerja}

Aklimatisasi Hewan Uji: Hewan yang digunakan dalam penelitian ini adalah rodentia tikus putih betina. Aklimatisasi tikus dilaksanakan di laboratorium Animal House Fakultas Kedokteran Universitas Islam Malang selama 1 minggu dengan suhu ruangan adalah $\pm 24^{\circ} \mathrm{C}$ dengan kelembaban udara kurang lebih $50-60 \%$ terjaga dari asap industri serta polutan lainnya dan diberikan makan dan minum. Aklimatisasi pada hari ke tujuh dilakukan pengukuran berat badan tikus untuk penentuan berat badan prakondisi dan dilakukan selama 7 hari sekali pada masa perlakuan. 
e-Jurnal Ilmiah BIOSAINTROPIS (BIOSCIENCE-TROPIC)

Volume 6/ No.: 2 / Halaman 58 - 63 / Januari Tahun 2021

ISSN : 2460-9455 (e) - 2338-2805(p)

Ekstraksi: Ekstraksi benalu teh dan mangga memakai metode maserasi. Setelah proses seleksi daun, pengovenan didapatkan simplisia bubuk kemudian setiap simplisia benalu teh dan mangga ditimbang 100 gram selanjutnya dimasukkan ke dalam botol dengan ukuran 1,5 Liter. Tahap selanjutnya perendaman menggunakan methanol 90\% sebanyak 1 liter. Kemudian dikocok selama 1 jam hingga larutan homogen. Selanjutnya ekstrak didiamkan dan diendapkan selama 24 jam agar dinding sel daun benalu teh dan daun benalu mangga pecah. Zat aktif dalam daun dapat dikeluarkan oleh pelarut methanol. Hasil perendaman selama 24 jam akan membentuk dua lapisan berupa supernatant dan natant. Hasil Supenatant inilah yang ditampung dan dilanjutkan dengan tahapan ekstraksi dengan menggunakan rotary evaporator. EMBTBM diberikan pada 3 perlakuan selain kontrol, diberikan dengan cara sonde selama 28 hari dengan dosis $250 \mathrm{mg} / \mathrm{kgBB}, 500 \mathrm{mg} / \mathrm{kgBB}, 1000 \mathrm{mg} / \mathrm{kgBB}$. Volume Sonde EMBTBM diberikan sebanyak $1 \mathrm{ml} / 100 \mathrm{~g}$ BB setiap harinya, dan berat badan tikus putih ditimbang dua kali dalam satu minggu. Tikus dibedah dan darah diambil, kemudian organ ginjal pada hari ke-29 untuk diperiksa kadar urea, bun, kreatinin, dan histopatologi.

Pemeriksaan Sampel darah: Sejumlah $50 \mu L$ serum uji direaksikan dengan $1000 \mu L$ pereaksi uji untuk pemeriksaan kreatinin dalam tabung reaksi $5 \mathrm{~mL}$, kemudian dihomogenkan dengan bantuan vortex. Absorbansi diukur dengan menggunakan spektrofotometer pada suhu $37^{\circ} \mathrm{C}$ tepat setelah 60 detik pada panjang gelombang $492 \mathrm{~nm}$ (A1), kemudian diukur lagi absorbansi tepat setelah 120 detik (A2). Hal yang sama juga dilakukan terhadap blangko (pereaksi+aquades) dan standar (pereaksi+standar kreatinin).

Pemeriksaan Histopatologi: Organ ginjal ditempatkan dalam buffer $\mathrm{KCl} \&$ PBS $25 \mathrm{mM}$, kemudian disimpan dalam formaldehida buffered netral $40 \%$ pada suhu kamar. Bagian hematoxylin dan eosin (H\&E) $(\sim 5 \mu \mathrm{m})$ disiapkan untuk mengukur histopatologi. Bagian organ difoto pada perbesaran $400 \mathrm{x}$ menggunakan mikroskop Olympus (Tokyo, Jepang). Pencahayaan mikroskop, fokus, dan pemilihan bidang dioptimalkan untuk membedakan batas sel. Gambar dibuka dan setelah menetapkan ambang batas, dianalisis. Data semua bidang digabungkan dan kemudian dianalisis.

Analisis Data: Data diolah menggunakan uji ANOVA menggunakan aplikasi Jamovi versi 1.0.

\section{Hasil dan Diskusi}

\section{Hasil Penelitian}

Berdasarkan hasil kadar BUN dan Urea tidak terdapat perbedaan yang signifikan antara kelompok kontrol dan perlakuan $(\mathrm{p}<0.05)$ meskipun pada kelompok kontrol cenderung sedikit lebih tinggi. Berarti pemberian kombinasi ekstrak hingga dosis tertinggi yaitu $1000 \mathrm{mg} / \mathrm{kgBB}$ (P3) masih aman pada fungsi ginjal. Sementara untuk kadar kreatinin, tidak ada beda signifikan antara kelompok kontrol dengan perlakuan dosis 250 (P1) dan 1000 (P3) mg/kgBB (p>0.05), sedangkan pada dosis 500 $\mathrm{mg} / \mathrm{kgBB}$ lebih rendah signifikan dibandingkan kelompok kontrol $(\mathrm{p}<0.05)$ artinya pemberian EMBTBM menurunkan kadar kreatinin, BUN, dan urea karena dilihat pada penurunan dari perlakuan kontrol ke P1, P2, P3.

Tabel 5.4 Hasil Biokimia Darah Tikus setelah Pemberian Kombinasi Benalu Teh dan Benalu Mangga terhadap Fungsi Ginjal.

\begin{tabular}{|c|c|c|c|}
\hline Perlakuan & BUN $(\mathrm{mg} / \mathrm{dL})$ & Urea $(\mathrm{mg} / \mathrm{dL})$ & Kreatinin $(\mathrm{mg} / \mathrm{dL})$ \\
\hline Kontrol $(\mathrm{K})$ & $27,28 \pm 4,15 \mathrm{~ns}$ & $58,34 \pm 8,82 \mathrm{~ns}$ & $0,65 \pm 0,03 \mathrm{~ns}$ \\
\hline P.1 $(250 \mathrm{mg} / \mathrm{kgBB})$ & $24,9 \pm 6,03 \mathrm{~ns}$ & $53,26 \pm 12,94 \mathrm{~ns}$ & $0,64 \pm 0,04 \mathrm{~ns}$ \\
\hline P.2 $(500 \mathrm{mg} / \mathrm{kgBB})$ & $26,8 \pm 5,17 \mathrm{~ns}$ & $57,34 \pm 11,05 \mathrm{~ns}$ & $0,62 \pm 0,05 \mathrm{~ns}$ \\
\hline P.3 $(1000 \mathrm{mg} / \mathrm{kgBB})$ & $24,96 \pm 15 \mathrm{~ns}$ & $53,4 \pm 4,57 \mathrm{~ns}$ & $0,65 \pm 0,03 \mathrm{~ns}$ \\
\hline
\end{tabular}

Keterangan : Hasil uji ANOVA ( $>>0,05)$, ns) menunjukkan perlakuan P1, P2, dan P3 tidak berbeda nyata dengan kontrol. 
e-Jurnal Ilmiah BIOSAINTROPIS (BIOSCIENCE-TROPIC)

Volume 6/ No.: 2 / Halaman 58 - 63 / Januari Tahun 2021

ISSN : 2460-9455 (e) - 2338-2805(p)

Tabel 2. Hasil Piknotik Histopatologi Ginjal Tikus Wistar Betina Setelah Pemberian Kombinasi

Benalu Teh dan Benalu Mangga (EMBTBM) Selama 28 Hari.

\begin{tabular}{|c|c|c|c|c|c|}
\hline \multicolumn{4}{|c|}{ Histopatologi Ginjal Tikus Wistar Betina } \\
\cline { 1 - 5 } No. & Perlakuan & \multicolumn{3}{c|}{ Jumlah Sel Piknotik } & Rerata \pm SD \\
\cline { 3 - 5 } & & 1 & 2 & 3 & \\
\hline 1 & Kontrol $(\mathrm{K})$ & 31 & 36,67 & 36 & $34,56 \pm 3,10 \mathrm{a}$ \\
\hline 2 & P1 $(250 \mathrm{mg} / \mathrm{kgBB})$ & 36,33 & 31,33 & 36 & $34,55 \pm 80 \mathrm{a}$ \\
\hline 3 & $\mathrm{P} 2(5000 \mathrm{mg} / \mathrm{kgBB})$ & 35 & 34 & 33,67 & $34,22 \pm 0,69 \mathrm{a}$ \\
\hline 4 & P3 $(1000 \mathrm{mg} / \mathrm{kgBB})$ & 32 & 37 & 32 & $33,67 \pm 89 \mathrm{a}$ \\
\hline
\end{tabular}

Keterangan : Hasil uji ANOVA ( $>>0,05)$ menunjukkan semua perlakuan P1, P2, dan P3 tidak berbeda nyata dengan kontrol.
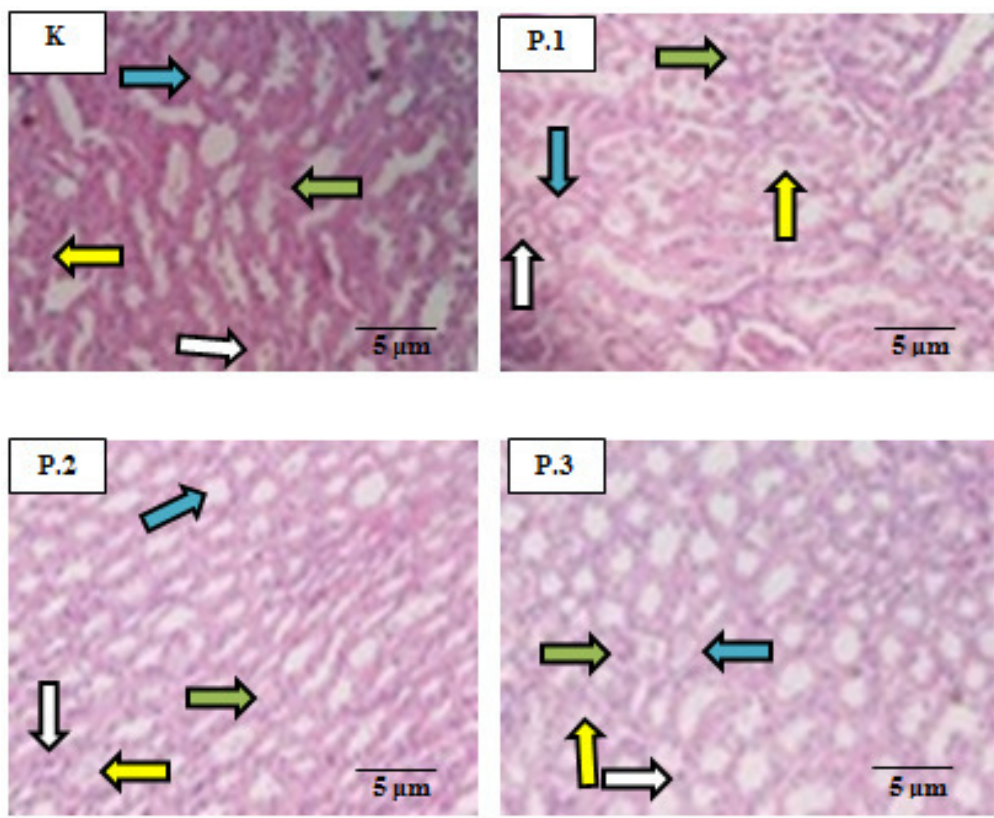

Gambar 1. Histopatologi Ginjal Setelah Pemberian EMBTBM 28 Hari (Mikroskop Cahaya Binokuler Olympus CX21, 40x10)

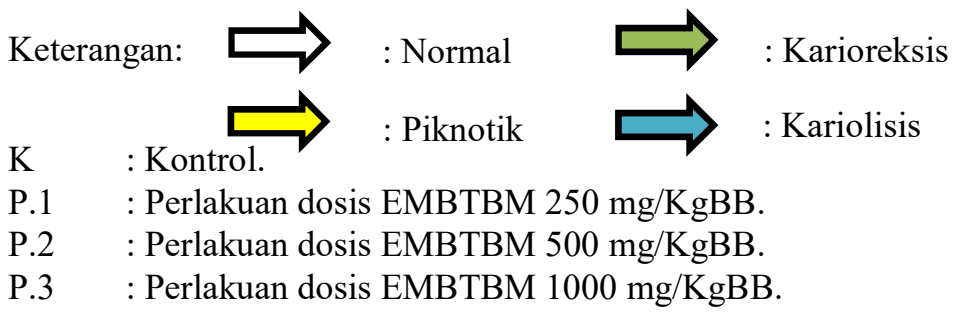

Berdasarkan Tabel 2, rerata kerusakan sel (nekrosis) piknotik ginjal pada kelompok kontrol (K) menunjukkan rerata sebesar 34,56. Sedangkan kelompok perlakuan 1 (P1) dengan EMBTBM dosis $250 \mathrm{mg} / \mathrm{KgBB}$ mengalami penurunan jumlah rerata sel piknotiknya sebesar 34,55. Kelompok perlakuan 2 (P2) dengan EMBTBM dosis $500 \mathrm{mg} / \mathrm{KgBB}$ menurun sebesar 34,22 dan kelompok perlakuan 3 (P3) dengan EMBTBM dosis $1000 \mathrm{mg} / \mathrm{KgBB}$ juga menurun sebesar 33,67. Pemberian EMBTBM ini menunjukkan bahwa tidak ada kerusakan pada sel ginjal berdasarkan sel yang mengalami piknotik. 
e-Jurnal Ilmiah BIOSAINTROPIS (BIOSCIENCE-TROPIC)

Volume 6/ No.: 2 / Halaman 58 - 63 / Januari Tahun 2021

ISSN : 2460-9455 (e) - 2338-2805(p)

\section{Pembahasan}

Berdasarkan tabel 1, didapatkan hasil pemberian ekstrak metanolik (EMBTBM) dosis 250, $500,1000 \mathrm{mg} / \mathrm{KgBB}$ cenderung menurunkan kadar urea, bun, dan kreatinin dan rerata semua perlakuan dianalisis SPSS tidak berbeda nyata dengan kontrol. Berdasarkan tabel 2. dan gambar 1, pemberian ekstrak metanolik EMBTBM dosis $250,500,1000 \mathrm{mg} / \mathrm{KgBB}$ cenderung menurunkan jumlah sel yang mengalami piknotik, karioreksis, dan kariolisis dan rerata semua perlakuan dianalisis SPSS tidak berbeda nyata dengan kontrol.

Perlakuan dengan pemaparan EMBTBM dengan dosis berbeda didapatkan hasil kadar urea, BUN, dan kreatinin lebih rendah dari kontrol. EMBTBM berpotensi sebagai obat-obatan untuk menyembuhkan berbagai penyakit seperti antihipertensi, antikanker dan anti inflamasi karena kandungan senyawa aktif yang terkandung didalamnya adalah flavonoid. Zat Kuersetin merupakan salahsatu flavonoid berupa glikosida. Flavonoid berfungsi menangkap radikal bebas yang ada dalam tubuh, menghambat suatu enzim hidrolisis dan oksidatif serta melengkapi defisit elektron pada radikal bebas. Flavonoid menghambat terjadinya reaksi berantai dalam pembentukan radikal bebas serta memperbaiki kerusakan membran sel melalui mekanisme scanger. Hal ini dapat mencegah kerusakan sel-sel glomerulus [9]. Salah satu penyebab peningkatan radikal bebas yang adalah faktor Shear stress. Adanya faktor stress terjadi saat proses pemeliharaan tikus dapat meningkatkan radikal bebas, beberapa kemungkinan yang dapat menyebabkan tikus menjadi stress yakni perbandingan luas kandang dengan populasi tikus yang diduga kurang efektif, distribusi diet tikus yang kurang merata dang gangguan perilaku antar hewan uji dan proses pemberian EMBTBM pada hewan uji Rattus norvegicus. Kreatinin memiliki pengertian yaitu bentuk anhidrida dari kreatin yang mayoritas zatnya disintesis di dalam otot melalui proses dehidrasi non-enzimatik dari kreatin fosfat [10]. Selain di otot, kreatinin terdapat di dalam otak dan darah dalam bentuk fosfokreatin maupun bentuk bebas. Kreatinin diekskresikan seluruhnya kedalam urin melalui filtrasi glomerulus. Rusaknya fungsi ginjal ditandai dengan meningkatnya kadar kreatinin [11]. Kadar normal kreatinin dan ureum secara berurutan adalah sekitar 0,5-0,8 mg/dl dan 28,79-68,18 mg/dl [12]. Peningkatan kreatinin disebabkan adanya radikal bebas. Radikal bebas dapat diartikan suatu molekul yang memiliki satu elektron yang tidak berpasangan di orbital atau senyawa yang begitu tidak stabil disebabkan struktur atom atau molekul tersebut. Sehingga, radikal bebas menjadi sangat bereaksi mencari pasangan dengan atom lain, atau bahkan elektron tunggal untuk meciptakan senyawa yang stabil. Radikal bebas dan Reactive Oxygen Species (ROS) menginduksi stress oksidatif dalam organ ginjal. Peningkatan radikal bebas dan ROS akan mengakibatkan terjadinya kematian sel dimana sistemnya isi-isi sel yang keluar akan melakukan ikatan dengan protein fibronektin di dalam lumen tubular. Hal ini akan mengakibatkan penyumbatan berupa silinder sehingga kreatinin tidak bisa dikeluarkan dengan baik [13].

Kerusakan sel ginjal tikus betina kelompok EMBTBM dengan pemberian dosis 250, 500, dan $1000 \mathrm{mg} / \mathrm{KgBB}$ menurunkan jumlah sel yang mengalami nekrosis atau kerusakan. Nekrosis sel ginjal bisa digambarkan dengan melihat sel yang piknotik, karioreksi, dan kariolisis.

\section{Kesimpulan}

Pemberian ekstrak kombinasi Scurulla atropurpurea dan Dendrophthoe pentandra pada tikus betina Rattus novergicus pada paparan subkronik 28 hari dengan dosis $250 \mathrm{mg} / \mathrm{KgBB}, 500 \mathrm{mg} / \mathrm{KgBB}$, dan $1000 \mathrm{mg} / \mathrm{KgBB}$ dapat menurunkan nilai kadar kreatinin, bun, dan urea, jumlah sel ginjal yang mengalami piknotik, karioreksis, dan kariolisis, serta cenderung aman dan tidak menimbulkan sifat toksik pada kerusakan fungsi ginjal tikus wistar betina.

\section{Ucapan Terima Kasih}

Terima kasih kepada Direktorat Riset dan Pengabdian Masyarakat, Kementerian Riset, Teknologi, dan Pendidikan Tinggi Republik Indonesia, Nomor: 112/G164/U.LPPM/K/B.07/IV/2019, yang telah 
e-Jurnal Ilmiah BIOSAINTROPIS (BIOSCIENCE-TROPIC)

Volume 6/ No.: 2 / Halaman 58 - 63 / Januari Tahun 2021

ISSN : 2460-9455 (e) - 2338-2805(p)

mendukung dana hibah untuk penelitian Penelitian Strategis Nasional dengan judul "Sediaan Herbal

Benalu Teh sebagai Kandidat Alternatif Obat Antihipertensi Alami Tradisional Indonesia".

\section{Daftar Pustaka}

[1] Okoli, M. J.K, R. I., Turay, A. A. and Efosa, O.-O. 2009. Phytochemical analysis of medicinal plants used for the management of hypertension by Esan people of Edo state, Nigeria," Ethnobot. Leafl., vol. 13, no. 1, pp. 1273-1287.

[2] Athiroh AS, N. and Permatasari, N. 2012. Mekanisme Kerja Benalu Teh pada Pembuluh Darah Mechanism of Tea Mistletoe Action on Blood Vessels," J. Kedokt. Brawijaya, vol. 27, no. 1, pp. 1-7.

[3] Zahroh, D. F., As, N. A. and Santoso, H. 2017. Efek Pemberian Ektrak Metanolik Scurrula atropurpurea (Bl) Dans Terhadap Kadar Kolesterol Tikus Wistar Secara Subkronik," J. Ilm. BIOSAINTROPIS, vol. 3, no. 1, pp. 8-14.

[4] Athiroh, N. and Sulistyowati, E. 2013. Scurrula atropurpurea increases nitric oxide and decreases malondialdehyde in hypertensive rats," Universa Med., vol. 32, no. 1, pp. 44-50.

[5] Athiroh, N., Permatasari, N., Sargowo, D. and Widodo, M. A.2014. Antioxidative and blood pressure-lowering effects of Scurrula atropurpurea on deoxycorticosterone acetate-salt hypertensive rats," Biomarkers Genomic Med., vol. 6, no. 1, pp. 32-36.

[6] Athiroh, N., Permatasari, N., Sargowo, D. and Widodo, M. A.2014. Effect of Scurrula atropurpurea on nitric oxide, endothelial damage, and endothelial progenitor cells of DOCA-salt hypertensive rats," Iran J Basic Med Sci, vol. 17, no. 8, p. 2014.

[7] Noer, M. S. 2006. Evaluasi fungsi ginjal secara laboratorik (Laboratoric evaluation on renal function). Universitas Airlangga. Surabaya.

[8] Prastika, N. I., Athiroh, N. and Santoso, H. 2017. Pengaruh Pemberian Subkronik Ekstrak Metanolik Scurrula atropurpurea (B1) Dans Terhadap Kadar Kreatinin Tikus Wistar," J. Ilm. BIOSAINTROPIS, vol. 2, no. 2, pp. 42-48.

[9] Asker, M., Asker, S. F., Mohamed, F. M. and Ali, O. H. 2007.Chemical Structure and Antiviral Activity of Water-soluble Sulfated Polysaccharides from Surgassum latifolium," J. Appl. Sci. Res., vol. 3, no. 1, pp. 1178-1185.

[10] Sumaryono, W. et al., 2008. Analisis Urea-Kreatinin Tikus Putih pasca Pemberian Ekstrak Buah Mahkota Dewa dan Herba Pegagan," J. Ilmu Kefarmasian Indones., vol. 6 , no. 1, pp. 35-40.

[11] Pearce, E. C. 2009. Anatomi dan Fisiologi untuk Paramedis. Gramedia Pustaka Utama.

[12] Jumiarni, W. O. and Komalasari, O. 2017. Eksplorasi Jenis Dan Pemanfaatan Tumbuhan Obat Pada Masyarakat Suku Muna Di Permukiman Kota Wuna, Tradit. Med. J., vol. 22 , no. 1, pp. 45-56.

[13] Michael, I. Kusharyanti, and Isnindar. 2013. Pengaruh ekstrak metanol daun Kesum (Polygonum minus Huds.) terhadap peningkatan kadar kreatinin dan ureum serum tikus putih galur Wistar terinduksi sisplatin. J. Mhs. Farm. Fak. Kedokt. UNTAN, vol. 1, no. 1, pp. 1-9. 